\title{
Head Teachers' Prevalent Leadership Styles and Teachers' Performance in Selected Private Secondary Schools in Buikwe District
}

\author{
John of God Masaaba1, Victoria Kaggwa Tamale², Gyaviira Musoke Genza ${ }^{3 *}$
}

Article History:
Received 05.10.2020
Received in revised
form 07.08 .2021
Accepted
Available online
01.10.2021

\begin{abstract}
Due to the multiplicity of variables that come into play to explain employee performance, recent research has questioned the role of prevalent leadership styles in teacher performance. Inspired by such narratives, the current study set out to examine the prevalence of different leadership styles among head teachers, and to relate the prevalent styles to teacher performance in selected private secondary schools in Buikwe District. Using a correlational cross-sectional survey design, the study subjected 165 teachers and ten head teachers to a questionnaire and interview guide, respectively. Results indicated that teamwork is the most prevalently used leadership style, and that it has a positively significant but weak relationship with teacher performance. The study's strongest contribution lies in its extension of leadership style narratives to a rural private secondary school setting (in Uganda), and its identification of the teamwork style's limitations, its prevalence and immense value in educational administration and management notwithstanding.
\end{abstract}

C) IJERE. All rights reserved

Keywords: Head teacher, leadership, leadership style, teacher performance

\section{INTRODUCTION}

Performance' is the catchword in organisational theory today - and why not, since organisations come into existence to realise given goals, and thus 'to perform'? (Davidescu, Apostu, Paul \& Casuneanu, 2020; Igunnu,2020; Yalçınkaya, Dagli, Altınay, Altınay \& Kalkan 2021). Yet reports of chronic poor performance in education are common in many countries, including Uganda (MoES, 2017, 2019; Zikanga, Anumaka, Tamale \& Mugizi, 2021). Particularly for Buikwe District, the reports complain about teacher absenteeism and inadequate lesson planning, as well as teacher unwillingness (or even refusal) to get conscientiously involved in learner supervision, guidance, and counselling (Kiwanuka, 2017; Kakonge, 2018). The Buikwe District DEO's Report 2018 indicates that some teachers habitually arrive at their work stations as late at 10:00 am (two hours late), and that on Fridays only about $60 \%$ of teachers turn up for work (Buikwe District, 2018). The report further reveals that some of the head teachers rarely interact with teachers to involve them personally; others rarely appear in office to execute their duties (Buikwe District, 2018).

Since some studies posited that with an appropriate head teacher leadership style in a school, teachers are motivated to perform effectively (Adepoju, 2018; Küçüker, 2020; Yalçınkaya et al., 2021); the current study wondered if application of inappropriate leadership style(s) could be the problem in Buikwe District. If yes, what are those 'inappropriate' styles? Might certain leadership styles be more closely associated with superior teacher performance than others? What is the prevalence of different leadership styles in Buikwe District? It was feared that unless answers to these questions were found, poor teacher performance would continue in the district, hence failure to realise quality education as set out in both SDG 4 (Nakidien, Singh \& Sayed, 2021) and Uganda's Vision 2040 (GoU, 2013). Head teachers' leadership styles were thought to constitute an outstanding factor because in Uganda head teachers play the most important role in school level teacher supervision (MoES, 2008; Ssekamwa, 2000).

The study's purpose was to examine the prevalence of different leadership styles among head teachers in selected private secondary schools in Buikwe District, and to relate the styles to teacher performance. More specifically, the study sought to find out the prevalence of different leadership styles, and to examine the relationship between the prevalent styles and teacher performance.

\section{STUDY BACKGROUND}

'Teacher performance' pivots around the way teacher behaviours contribute to school goals (Davidescu, Apostu, Paul \& Casuneanu, 2020). Thus, Yalçınkaya et al. (2021), Okeniyi (1995) and Olaniyan (1999) have described 'teacher performance' as teachers' ability to combine different inputs for the achievement of school goals and objectives, particularly teaching and learning. Genza, Muwagga and Ssempala (2016) further indicate that teacher performance falls under eight roles; namely, classroom

\footnotetext{
${ }^{1}$ School of Education, College of Education \& External Studies, Makerere University, Uganda

${ }^{2}$ School of Education, College of Education \& External Studies, Makerere University, Uganda

${ }^{3}$ Orcid.org/0000-0002-5927-8731; School of Education, College of Education \& External Studies, Makerere University, Uganda

* Corresponding author: Gyaviira.genza@mak.ac.ug
} 
instruction, guidance and counseling, role modeling, leadership and management, educational research, community development, collegiality (team role) and co-curricular activities. The current study conceptualised teacher performance in terms of accomplishment of the roles of classroom instruction, guidance and counselling, collegiality and co-curricular activities since these constitute the core functions of a secondary school teacher in Buikwe District (Kakonge, 2018).

Consequently, a teacher was understood to be a person who performs the roles of lessons planning, teaching, assessing and evaluating students, communicating students' progress to parents, enforcing discipline, supervising students in co-curricular activities, conducting in-class activities, planning field studies and preparing students for final exams (Bencherab \& Maskari, 2021;Janelle, 2018; Muza, 2021). Thus, in this study, a teacher is someone who aids learners to acquire knowledge, skills and values, and it is along these lines that teacher performance is construed. This study's teacher operates in a private secondary schools - a post primary school that is owned by an individual or by a group such as a church, and therefore relies on internally-generated resources to run (MoES, 2008). The study was localised in private schools because they are the majority in Uganda and are assumed to be better in terms of headship and teacher performance (Crawfurd, 2017).

The education officer who heads a secondary school in Uganda is known as a head teacher (MoES, 2008). It is the head teacher who organizes and co-ordinates a school's human and material resources for the purpose of achieving institutional goals (Adepoju, 2018). His/her role includes leadership, which is about influencing both teaching and non-teaching staff to perform well to achieve school goals (Goddey, 2017). It is indeed the leadership style of the head teacher that sets the overall tone of the school, level of professionalism and teacher morale. The style adapted by such an officer can be of paramount importance in determining teacher performance (Holberta, Madhakomala, Saparuddin \& Timotius, 2021; Iqbal, Anwar \& Haider, 2015). This study therefore contends that the head teacher's effectiveness in influencing teachers to work together (teamwork), involve themselves in co-curricular activities, instruct students, and give them guidance and counseling largely depends on the overriding way (style) in which the head teacher interacts with teachers.

These 'ways of interacting' are technically referred to as 'leadership styles' - the different behaviours of influencing others to work towards attainment of group goals (Genza, 2021; Khan, Ismail, Hussain \& Alghazali, 2020; Blasé, Dedrick \& Strathe, 2018; Bush \& Middlewood, 2005; Wachira, Gitumu \& Mbugua, 2017). Available literature categorises leadership styles differently. However, guided by Blake and Mouton's Managerial Grid (1964), which was later (1985) termed 'Managerial Model III', the current study categorised the styles into five along lenses of one's concern for production (task) and concern for people (Blake \& Mouton, 1985). Depending on the kind of style or concern demonstrated by the leader, employees will respond with enthusiasm or resentment, involvement or apathy, commitment or indifference (Blake et al., 1985).

The model's behavioural dimension of concern for production is plotted on the X-axis on a scale from one to nine points; and concern for people is plotted on a similar scale along the Y-axis. The point of intersection indicates one's pertinent leadership style. The Managerial Grid specifies five major leadership styles, namely; the indifferent style $(1,1)$, accommodating style $(1,9)$, middle-of-the-road $(5,5)$, dictatorial style $(9,1)$ and the team style $(9,9)$. Compared with other styles such as those of Fiedler's contingency leadership theory, Blake et al. (1985)'s styles were found to be both more elaborate and practical. Head teachers using this model can easily realise the importance of being concerned about teachers' needs, and this would positively impact on teaching and learning, and hence on school performance in general (Ahmed, 2015).

Indeed several researchers employed this same grid/model in related studies (Hakan, Kiliclar, \& Yazicioglu, 2013; Ahmed, 2015; Biradar \& Chatpalli, 2017; Cho, Yi \& Choi, 2018; Alonzo, 2018). For example, whereas Hakan et al. (2013) applied the grid in a study of Turkish managers' leadership styles, Cho et al. (2018) used it to examine the relationship between leadership type and organisational performance in South Korea. However, the two studies were in the medical, banking and telecommunications sectors, and not in education. The current study therefore borrowed Blake and Mouton's leadership styles, focusing on three styles; namely, the indifferent, dictatorial and teamwork styles. These three respectively align well with Lewin, Lippett and White's laissez- faire, autocratic, and democratic leadership styles (as cited by Joshi, 2015). The three have also been left out by some recent research (Esia-Donkoh \& Quansah, 2021).

In Uganda, where Buikwe District is located, teacher performance has differed over time (Zikanga et al., 2021). During the colonial era (1894-1962), performance was moderately high as it was closely monitored by (Anglican and Catholic) missionaries (Ssekamwa, 2000), who were both experienced and committed. 
However, soon after independence (in 1962), Government took over school control through the 1963 Education Act. This led to loss of effective school headship and supervision as the Act entrusted these roles mainly to inexperienced Inspectors of Schools appointed by the Ministry of Education. Secondly, with the return to Europe of many competent expatriate teachers (including head teachers) at Uganda's independence, both school administration and teaching were largely left in the hands of novices (Ssekamwa, 1997), including untrained teachers. When Asians were later expelled from Uganda in 1972, another critical shortage of experienced teachers and school administrators was created. Though the Government imported some graduates from Ghana, India, Bangladesh and Pakistan, the interruptions greatly impacted negatively on school leadership and teacher performance, as there was much discontinuity and amateurism (Ssekamwa, 1997). It should also be noted that in Uganda, teacher performance has long been linked to head teacher (principal) leadership as the accounting officer in a school (Ssekamwa, 2000). This makes the head teacher's overriding leadership style such an important variable in the success or failure of any school (Aunga, 2017). However, what is the current status of research on both leadership styles and their relationship with performance?

\section{LITERATURE REVIEW}

Concerning the prevalence of different styles (first study objective), literature indicated that teamwork, sometimes known as the participative style, was more frequently practiced than the other two coexisting styles, namely the autocratic and laissez-faire (Specchia et al., 2021; Akparep, Jengre \& Mogre, 2019; Yao, Woan, Li \& Ahmad, 2017). Some studies such as Munir and Iqbal (2018) did not only report teamwork as the most practiced style, but also graded the other two in terms of the dictatorial style coming next, and the indifferent being third - but 'hardly practiced'. However, according to Akparep et al. (2019)'s study (in Ghana), the democratic (close to teamwork) style, is followed, not by the dictatorial, but by the indifferent. This implies that also the realities from Uganda's Buikwe District schools could end up with results giving a schema of prevalent leadership styles that differs from those of the existing majority of studies. Moreover, some of the existing works such as Akparep et al. (2019) were not carried out in education but in the mainstream business sector (in Ghana); and others such as Yao et al. (2017) were in the context of Malaysia (in Asia). Akparep et al. (2019)'s study is further considered to be constrained by its design (qualitative case study) and sampling technique (solely purposive), hence quite limited to be generalized to education contexts in Uganda.

For the second objective, the study considered literature on the relationship between different leadership styles and employee performance. Regarding the indifferent (laissez-faire) style, some studies showed that it has a negative relationship to staff performance (Specchia et al., 2021; Aboshaiqal, Monsour, Sherrod, Alkhaibary \& Alkhaibary 2014; Ejimabo, 2015). However, others reported a positive relationship (Dastane, 2020; Imhangbe, Okecha \& Obozuwa, 2018; Basit et al., 2017; Yao et al., 2017; Al-Malki \& Juan, 2018). Yet others such as Chua, Basit and Hassan (2018) and Mawoli and Haruna (2017) simply reported that the indifferent style has little impact on job performance, without directly indicating the direction of the relationship (whether positive or negative). Such contradictions warranted the current study. Moreover, studies such as Aboshaiqal et al. (2014) were not carried out in the education sector but in engineering. It is Imhangbe et al. (2018)'s study which was in education (on principals' leadership styles and teacher job performance), but in both public and private secondary schools, moreover in the context of Nigeria (W. Africa). The current study was localized in Uganda (E. Africa), and more so in private schools only, whose leadership dynamics differ from those in public schools. Hypothesis 1: There is a relationship between head teachers' indifferent leadership style and teacher performance.

For the dictatorial (autocratic/authoritarian) leadership style, some studies indicated that it has a negative impact on employee performance (Basit et al., 2017; Iqbal et al., 2015; Nasir, Nordin, Seman \& Rahmat, 2014; Ayene, 2016). However, other studies found a positive correlation between dictatorial leadership and employee performance (Chua et al., 2018; Akram et al., 2012; Bakwai, 2015; Bhargavi \& Yaseen, 2016; Khajeh, 2018; Wang \& Guan, 2018). The contradiction gap between one group of studies and another warranted further research, among other gaps. Hypothesis 2: There is a relationship between head teachers' dictatorial leadership style and teacher performance.

Lastly, most of the available studies indicated that there is a positive relationship between the teamwork (or participative / supportive) leadership style and employee performance (Ghodang, 2021; Dastane, 2020; Sanyal \& Hisam, 2018; Sarışık,2020; Wachira et al., 2017; Agwu, 2015; Aunga et al., 2017; Khan 
et al., 2017; Basit et al., 2017). Some studies even give a comparative element, indicating that the teamwork style contributed more to staff productivity than other styles (Yao et al., 2017; Dalluay \& Jalagat, 2016). However, none of these studies was carried out in Uganda and some of them were outside education. For example, whereas Dastane (2020) was among employees of multinational corporations in Malaysia, Agwu (2015) was in the oil and gas sector in Nigeria, and Khan et al. (2017) was in the banking sector in Oman. Though in education, Sanyal et al. (2018)'s study concerned itself with the university level (in Oman), and Aunga et al. (2017) went for the primary school level (in Arusha, Tanzania). The current study felt that the secondary school level was under studied, except for Wachira et al. (2017)'s study in Kieni-West Sub-County, Kenya, which however interested itself only in public secondary schools, excluding private ones. The current study therefore went for private (not public) secondary (not primary or tertiary) schools. Hypothesis 3: There is a relationship between head teachers' teamwork leadership style and teacher performance.

\section{METHODOLOGICAL UNDERPININGS}

The study employed a correlational cross-sectional survey design (Amin, 2005) that utilized both quantitative and qualitative approaches so as to realise a wider view of reality. Head teachers and teachers in private secondary schools in Buikwe District constituted the target population. The sample size was 165 teachers, arrived at using Krejcie and Morgan (1970)'s tables. For sampling, the study employed stratified random and purposive sampling techniques to teachers and head teachers, respectively. Questionnaire and interview guide were the study tools.

The questionnaire was adapted from Ahmed (2015) and Genza et al. (2016), and had nine (9) indicators of teacher performance (DV), namely: scheme of work preparation; lesson plan preparation; updating lesson notes; use of a variety of teaching materials; offering guidance and counseling to students; monitoring student work; class management during instruction; applying a variety of teaching methods; team building; participation in co-curricular activities; monthly assessment of learning; and, attending to all lessons stipulated. For head teachers' leadership styles (IV), the different indicative elements for each style are indicated in Table 1 (below).

The questionnaire's internal validity was ensured using content validity (with a CVI of 0.85). External validity was achieved by using both ecological and population validity techniques (Khorsan \& Crawford, 2014). Reliability was ensured by adapting items from readymade tools from Ahmed (2015) and Genza et al. (2016), in addition to Cronbach's Alpha method (with all items ranging from 0.74 to 0.8). Pilot testing was also carried out for both tools. Quantitative data were analysed using descriptive statistics as well as Pearson's Linear Correlation Co-efficient. Qualitative data were analysed thematically.

For ethics, respondents' informed consent was ensured by explaining to them what the study was all about. With regard to the right to privacy, the study ensured anonymity of both respondents and schools by using pseudonyms. To ensure no harm is done to participants, Covid-19 SOPs (such as masking and social distancing) were adhered to.

In the end, the study's actual sample consisted of 159 teachers, of whom $102(64.2 \%)$ were male and 57 $(35.8 \%)$ were female. The majority $(93 \%)$ were $25-45$ years old; held first degrees $(77.4 \%)$; and had been teaching in private secondary schools in Buikwe District for a period of at least ten years $(82 \%)$. The participants were therefore from both genders, moreover with adequate experience in teaching in private schools in the study district, hence population validity.

\section{FINDINGS: ANALYSIS, INTERPRETATION AND DISCUSSION Prevalence of different leadership styles}

Table 1 presents a summary of the findings on the prevalence of the three different leadership styles among Head teachers of private secondary schools in Buikwe District (Uganda). 
Table 1: Prevalence of different leadership styles among head teachers

Leadership style

Respondents' answers

\begin{tabular}{|c|c|c|c|c|c|c|c|}
\hline 1 & Indifferent style (indicators) & SD & $\mathrm{D}$ & U & A & SA & $\overline{\mathbf{x}}$ \\
\hline & $\begin{array}{l}\text { My head teacher does not mind about my } \\
\text { conduct at school }\end{array}$ & $\begin{array}{c}108 \\
(68 \%)\end{array}$ & $\begin{array}{c}41 \\
(26 \%)\end{array}$ & $\begin{array}{c}5 \\
(3 \%)\end{array}$ & $\begin{array}{c}1 \\
(1 \%)\end{array}$ & $\begin{array}{c}4 \\
(2 \%)\end{array}$ & \multirow{5}{*}{1.61} \\
\hline & $\begin{array}{l}\text { My head teacher does not follow up my } \\
\text { availability at school }\end{array}$ & $\begin{array}{c}118 \\
(75 \%)\end{array}$ & $\begin{array}{c}30 \\
(19 \%)\end{array}$ & $\begin{array}{c}6 \\
(4 \%)\end{array}$ & $\begin{array}{c}2 \\
(1 \%)\end{array}$ & $\begin{array}{c}2 \\
(1 \%)\end{array}$ & \\
\hline & $\begin{array}{l}\text { My head teacher does not take initiative to } \\
\text { improve student performance }\end{array}$ & $\begin{array}{c}116 \\
(73 \%)\end{array}$ & $\begin{array}{c}34 \\
(21 \%)\end{array}$ & $\begin{array}{c}8 \\
(5 \%)\end{array}$ & $\begin{array}{c}0 \\
(0 \%)\end{array}$ & $\begin{array}{c}1 \\
(1 \%)\end{array}$ & \\
\hline \multirow{2}{*}{\multicolumn{2}{|c|}{$\begin{array}{l}\text { My head teacher exercises minimum } \\
\text { supervision of work }\end{array}$}} & $\begin{array}{c}65 \\
(41 \%) \\
\end{array}$ & $\begin{array}{c}46 \\
(29 \%)\end{array}$ & $\begin{array}{c}8 \\
(5 \%)\end{array}$ & $\begin{array}{c}24 \\
(15 \%)\end{array}$ & $\begin{array}{c}16 \\
(10 \%)\end{array}$ & \\
\hline & & $64 \%$ & $24 \%$ & $4 \%$ & $4 \%$ & $4 \%$ & \\
\hline & Overall & \multicolumn{2}{|c|}{$88 \%$} & $4 \%$ & \multicolumn{2}{|c|}{$8 \%$} & \\
\hline \multirow[t]{8}{*}{2} & Dictatorial style (indicators) & \multicolumn{5}{|c|}{ Respondents' answers } & $\overline{\mathbf{x}}$ \\
\hline & $\begin{array}{l}\text { My head teacher gives strict work rules not to } \\
\text { be questioned }\end{array}$ & $\begin{array}{c}22 \\
(14 \%)\end{array}$ & $\begin{array}{c}30 \\
(19 \%)\end{array}$ & $\begin{array}{c}16 \\
(10 \%)\end{array}$ & $\begin{array}{c}63 \\
(40 \%)\end{array}$ & $\begin{array}{c}27 \\
(17 \%)\end{array}$ & \multirow{7}{*}{2.78} \\
\hline & $\begin{array}{l}\text { My head teacher uses authoritarian } \\
\text { communication }\end{array}$ & $\begin{array}{c}81 \\
(51 \%)\end{array}$ & $\begin{array}{c}43 \\
(27 \%)\end{array}$ & $\begin{array}{c}11 \\
(7 \%)\end{array}$ & $\begin{array}{c}13 \\
(8 \%)\end{array}$ & $\begin{array}{c}11 \\
(7 \%)\end{array}$ & \\
\hline & $\begin{array}{l}\text { My head teacher minds about the task at } \\
\text { hand, no matter my health }\end{array}$ & $\begin{array}{c}15 \\
(10 \%)\end{array}$ & $\begin{array}{c}10 \\
(6 \%)\end{array}$ & $\begin{array}{c}5 \\
(3 \%)\end{array}$ & $\begin{array}{c}51 \\
(32 \%)\end{array}$ & $\begin{array}{c}78 \\
(49 \%)\end{array}$ & \\
\hline & My head teacher does not delegate authority & $\begin{array}{c}58 \\
(37 \%)\end{array}$ & $\begin{array}{c}53 \\
(33 \%)\end{array}$ & $\begin{array}{c}21 \\
(13 \%)\end{array}$ & $\begin{array}{c}20 \\
(13 \%)\end{array}$ & $\begin{array}{c}7 \\
(4 \%)\end{array}$ & \\
\hline & $\begin{array}{l}\text { My head teacher's word is usually final not to } \\
\text { be questioned }\end{array}$ & $\begin{array}{c}42 \\
(26 \%)\end{array}$ & $\begin{array}{c}53 \\
(33 \%)\end{array}$ & $\begin{array}{c}21 \\
(13 \%)\end{array}$ & $\begin{array}{c}28 \\
(18 \%)\end{array}$ & $\begin{array}{c}15 \\
(10 \%)\end{array}$ & \\
\hline & & $28 \%$ & $24 \%$ & $9 \%$ & $22 \%$ & $17 \%$ & \\
\hline & Overall & & & $9 \%$ & & & \\
\hline \multirow[t]{8}{*}{3} & Teamwork (indicators) & & Resp & dents' a & wers & & $\overline{\mathbf{x}}$ \\
\hline & $\begin{array}{l}\text { My head teacher involves teachers in decision } \\
\text { making }\end{array}$ & $\begin{array}{c}13 \\
(8 \%)\end{array}$ & $\begin{array}{c}14 \\
(9 \%)\end{array}$ & $\begin{array}{c}10 \\
(6 \%)\end{array}$ & $\begin{array}{c}71 \\
(45 \%)\end{array}$ & $\begin{array}{c}51 \\
(32 \%)\end{array}$ & \multirow{6}{*}{4.03} \\
\hline & $\begin{array}{l}\text { My head teacher conducts staff meetings } \\
\text { regularly }\end{array}$ & $\begin{array}{c}10 \\
(6 \%)\end{array}$ & $\begin{array}{c}9 \\
(6 \%) \\
\end{array}$ & $\begin{array}{c}7 \\
(4 \%)\end{array}$ & $\begin{array}{c}61 \\
(39 \%)\end{array}$ & $\begin{array}{c}72 \\
(45 \%)\end{array}$ & \\
\hline & $\begin{array}{l}\text { My head teacher allows teachers to express } \\
\text { their views }\end{array}$ & $\begin{array}{c}7 \\
(4 \%)\end{array}$ & $\begin{array}{c}9 \\
(6 \%)\end{array}$ & $\begin{array}{c}5 \\
(3 \%)\end{array}$ & $\begin{array}{c}71 \\
(45 \%)\end{array}$ & $\begin{array}{c}67 \\
(42 \%)\end{array}$ & \\
\hline & $\begin{array}{l}\text { My head teacher offers support supervision } \\
\text { to staff }\end{array}$ & $\begin{array}{c}7 \\
(4 \%)\end{array}$ & $\begin{array}{c}10 \\
(6 \%)\end{array}$ & $\begin{array}{c}9 \\
(6 \%)\end{array}$ & $\begin{array}{c}70 \\
(44 \%)\end{array}$ & $\begin{array}{c}63 \\
(40 \%)\end{array}$ & \\
\hline & $\begin{array}{l}\text { My head teacher works with teachers to } \\
\text { improve on their welfare }\end{array}$ & $\begin{array}{c}10 \\
(6 \%)\end{array}$ & $\begin{array}{c}10 \\
(6 \%)\end{array}$ & $\begin{array}{c}9 \\
(6 \%)\end{array}$ & $\begin{array}{c}75 \\
(47 \%)\end{array}$ & $\begin{array}{c}55 \\
(35 \%)\end{array}$ & \\
\hline & & $6 \%$ & $6 \%$ & $5 \%$ & $44 \%$ & $39 \%$ & \\
\hline & Overall & \multicolumn{2}{|c|}{$12 \%$} & $5 \%$ & \multicolumn{2}{|c|}{$83 \%$} & \\
\hline
\end{tabular}

Table 1 reveals that, according to teachers in private secondary schools in Buikwe District, the most prevalent head teacher leadership style is the teamwork style, with $83 \%$ of agreement ( $\bar{x}=4.03)$. The style got an overwhelming 'Yes' ('agreement') on each of the five indicative measures used. On the other hand, the dictatorial and indifferent styles got only $39 \%(\bar{x}=2.78)$ and $8 \%(\bar{x}=1.61)$ of agreement, respectively. These findings mean that teamwork and its related participatory practices are very common in Buikwe private secondary schools. These findings agree with Akparep et al. (2019) and Yao et al. (2017) that teamwork (participatory) style is more frequently practiced than either the dictatorial or the indifferent style.

During interview, the researchers made an attempt to appreciate more deeply why, where, when and how the teamwork style is practiced. Asked why this style, one Head teacher revealed that;

Two heads are better than one. I involve and consult the teachers so that we can share ideas, plan together and achieve together (Header teachers' interview) 
Concerning the where, when and how, the same respondent reported that;

It is mainly through my encounter with them [teachers] in the meetings, suggestions from the suggestion box or during the one on one sessions especially with the Heads of departments and class teachers (Header teachers' interview).

Meetings came out repeatedly as the most common platform for 'working together'. Thus, another respondent opined that;

Numerous meetings are held including beginning of term, weekly meetings for staff briefing, students' assessment meetings as well as end of term meetings. There are also monthly class meetings where the voice of the students is heard through their class teachers in the main staff meetings (Head teachers' interview).

This means that meetings are so important in the success of teamwork that without them it would stall. Even then, not everything is to be referred to a team meeting for discussion.

There are moments [issues] that require immediate action... where I cannot involve teachers, for example during students' grave indisciplinary cases and student health. There are also other sensitive matters reserved to my office especially pertaining to finances where I involve only the Board [of Governors] (Head teachers' interview).

These revelations mean that however good teamwork (via meetings) is, it should not be overdone, since consultation meetings also have a downside;

Meetings at times delay or hinder action as many teachers use them to sabotage the schools' plans, and so only a few meetings are held especially those connected to students' performance. Moreover meetings are costly in terms of transport and other sitting allowances (Head teachers' interview).

This means that staff meetings and consultations ought to be regulated. Otherwise some individuals use them to sabotage official business;

When you allow too much of teachers' views you may lose leadership stability especially in matters concerning their rights like allowances and salaries yet private schools especially in our rural areas like Buikwe are not assured of stable income. If teachers' views are not regulated they can lead to turmoil in the school (Head teachers' interview).

This implies that even for administrators who commonly use the teamwork style, there are instances where they resort to other styles, such as the dictatorial, otherwise chaos may result. This further means that application of teamwork itself demands that head teachers sometimes code-switch to other styles so that the gains achieved through 'teamwork' are not lost.

Table 1 further reveals that the second most prevalently used leadership style is the dictatorial, though with only $39 \%$ of prevalence, since the majority of teachers (52\%) disagreed that their head teachers employ it. These findings agree with Munir et al. (2018) that the dictatorial (autocratic) style is the second most frequently used style. The findings therefore disagree with Akparep et al. (2019)'s contention that the laissezfaire style is the second most commonly used style.

Surprisingly, on two (of the five) dictatorial style indicators the majority of teachers agreed on prevalence. The two are 'head teachers giving strict work rules not to be questioned' (57\%), and 'head teachers minding about the task at hand, no matter the teacher's health' (81\%). These findings mean that although generally head teachers in the private schools in Buikwe District use teamwork, when it comes to certain strategically critical issues such as student learning, they are ready to go dictatorial. One teacher explained that;

Academic performance is the trade mark of private schools in Uganda. Private schools survive on results and that is why many parents entrust their children to such schools. It is thus incumbent upon us [Head teachers] to live to that expectation through pressing and fostering teacher performance for as long as a school does not produce [academic] results, it has no students and consequently out of the education market. Thus, everything is done to achieve academic performance, including giving strict orders to teachers (Head teachers' interview).

Other Head teachers agreed, arguing, however, that it depends on the situation at hand. One put it this way; In certain situations, the more dictatorial a head teacher is, the more effective the teachers become and hence some need to be coerced in order to improve their performance. Different situations require different communication tones. There are instances when I reprimand my teachers especially those who miss classes, [and] those who regularly report late to school or class. Too much of consulting eats away the school's valuable time. So I apply some dictatorial measures especially where duty requires urgency (Head teachers' interview). 
On the practice of 'strict rules', head teachers indicated that it is mainly so as to avoid chaos at school. For example, one said that;

Rules and procedures protect the schools from disorder. Following school rules and policies pegged on the school vision and mission helps the teachers to understand what is expected of them and what will happen when they fail to observe or violate the rules (Head teachers' interview).

However, most interviewees further opined that staff rules should not be overdone;

Too many rules and procedures in schools break teachers' openness and collaboration and in the end it leads to tension and withdrawal from active participation. This equally affects [reduces] teacher performance (Head teachers' interview).

Finally, Table 1 reveals that use of the indifferent (laissez-faire) style is rare among Head teachers in the study schools. There was only $8 \%$ of agreement; with respondents overwhelmingly disagreeing on all the four style's indicative elements. This means that indifference is largely incompatible with the head teacher role because it [indifference] cannot deliver results. These findings concur with Specchia et al. (2021), Biradar et al. (2017) and Mawoli et al. (2017) that the indifferent leadership style is the least represented due to its ineffectiveness. The findings are also in line with Specchia et al. (2021) and Mawoli et al. (2017)'s recommendation that the use of the indifferent style should be discouraged since it creates a lawless working environment that retards performance. During interview, respondents explained why an indifferent style has no room in a private school. One reported that;

Student academic performance is at the center of private schools and so everything geared towards achieving this is very much promoted especially that of organizing and following up the human capital [teachers] to ensure teacher performance (Head teachers' interview).

Another respondent enumerated the stringent follow-up measures which her school uses;

In as far as responsibility and duty are concerned, we [Head teachers] work closely with the Deputy [incharge-of] administration, Deputy [in-charge-of] academics, class teachers, and Departmental heads in the supervisory role in view of getting the work done. We have also teachers on duty who take charge of the school's weekly activities in close link with us administrators, and presents a report to the entire staff at the beginning of another week. And there are also arrival books to check for teachers' attendance and availability at school, plus class attendance monitoring forms which every teacher signs every after a lesson, and is taken to the Director of studies. It is serious business, no joke! (Head teachers' interview).

Existence of such stringent measures explains why the indifferent style is out of place among head teachers in private secondary schools.

The next sub-section relates prevalent leadership styles to teacher performance. Incidentally, only the teamwork style was found to be prevalent in the study context, and therefore only its hypothesis (Hypothesis 3) was tested. Since respondents had indicated that the indifferent and dictatorial styles were largely absent among their head teachers (Table 1), going ahead to relate these two styles to teacher performance would only have been of mere hypothetical value, not of real value.

\section{Teamwork leadership style and teacher performance}

After a histogram had confirmed the normality of results on teamwork - with most of the scores tending to concentrate towards a mean score of 4.3 (with a small Standard Deviation of 0.82), the researchers went ahead to test the current objective's hypothesis using Pearson's linear correlation analysis. The results are presented in Table 2 .

Table 2: Correlation of Head teachers' teamwork style with teacher performance

\begin{tabular}{llll}
\hline & & Teamwork & Performance \\
\hline \multirow{3}{*}{ Teamwork } & Pearson's correlation & 1 & $0.181^{*}$ \\
& Sig. (2-tailed) & - & 0.022 \\
\multirow{3}{*}{ Performance } & N & 159 & 159 \\
& Pearson's correlation & $0.181^{*}$ & 1 \\
& Sign. (2-tailed) & 0.022 & - \\
& N & 159 & 159 \\
\hline
\end{tabular}

*. Correlation is significant at the 0.05 level (2-tailed) 
Table 2 reveals that there is a significant, positive but weak correlation between Head teachers' teamwork leadership style and teachers' performance $\left(\mathrm{r}=0.181^{*}\right.$; at $\left.\mathrm{p}<0.05\right)$. This means that the more head teachers employ teamwork, the more (or the better) teachers perform. Thus, the hypothesis that there is a relationship between head teachers' teamwork leadership style and teacher performance is supported by realities in private secondary schools in Buikwe District. However, since the correlation is a weak one $(\mathrm{r}=$ 0.18 ), it means that the style succeeds in improving teacher performance by only about $18 \%$. There are other critical factors that account for the remaining $82 \%$, which, however, were outside the current study's scope.

The above correlation results concur with Ghodang (2021), Dastane (2020), Akparep et al. (2019), Sanyal et al. (2018), Khan et al. (2017), Agwu (2015), Dalluay et al. (2016), Aunga et al. (2017), Wachira et al. (2017), and Yao et al. (2017) that there is a positive relationship between the teamwork leadership style and employees' performance. However, the correlation is quite low (18\%). Iqbal et al. (2015) attributes this to the fact that the style consumes a lot of time, hence eventual demotivation of both head teachers and teachers. Concurring voices were heard during interview, for example one head teacher observed that;

Too much of consulting eats away the school's valuable time. So I apply some dictatorial measures especially where duty requires urgency (Head teachers' interview).

Such a view implies that however relevant the team work style is in inducing teacher performance, a sporadically gauged borrowing from other styles (such as the dictatorial) might also be necessary. This is particularly true for emergencies such as fire outbreaks and violent student strikes.

\section{CONCLUSIONS}

The study concludes that, first, teamwork is the style of leadership that is most prevalently used by private secondary school head teachers in Buikwe District. This tells us both about teamwork (as a style of leadership) and about head teachers (as those that apply the style). For teamwork, it means that teamwork (still) works, and it works particularly in a private school setting. Teamwork is real in private educational institutions; it is one of the factors that drives schools. Concerning head teachers, the conclusion means that they overwhelmingly view and practice school administration as 'a joint effort' - an orchestra, not a one person's show. This further means that head teachers appreciate the wealth of expertise which different members of staff have, hence tapping into it through teamwork.

Secondly, the study concludes that the indifferent style is hardly practicable in a private secondary school setting. This means that for institutions that want to see results, 'indifference' - even in the name of 'personal freedom' - is a wrong path. Whereas schools periodically get emergency situations justifiably requiring application of the autocratic / dictatorial style, situations warranting an indifferent (free-reign) approach are difficult to imagine. May be using 'indifference' only as a provisional strategy towards one teacher's conduct as the administrator studies it more.

Lastly, the study concludes that the teamwork leadership style is truly positively associated with teacher performance. Because it brings teachers on board, particularly by consulting them through meetings, assigning them responsibilities and giving them professional support, the style succeeds in motivating teachers to work. This means that when teachers are both empowered and supported they deliver results. Even then, teamwork does not mean abdicating responsibility. As the accounting officers in the schools entrusted to them, head teachers still remain in-charge, and take the 'final' decision(s), even when it means going against the majority. For example, not every issue needs to be subjected to a 'majority vote'! However, since the correlation yielded a weak (though significant and positive) relationship between teamwork and teacher performance, the study contends that there are certain 'miracles' which this leadership style cannot perform - if it is left alone on its own without putting other factors into consideration. One such factor appears to be financial rewards. However, the current study did not delve deep into those other factors.

\section{RECOMMENDATIONS}

Head teachers should continue applying the teamwork leadership style because it facilitates complex task accomplishment, and is a source of dynamic capability that ensures long-term organisational effectiveness. However, teamwork alone cannot go far in inducing teacher performance. It should be used in tandem with other practices such as equitable teacher remuneration. The dictatorial leadership style should not necessarily be condemned as an inappropriate style. In itself, this style is not really 'inappropriate' or unacceptable. There are issues and situations that require it, such as health emergencies, fire outbreaks and violent strikes. 
However, the style should not become the routine style used by any head of school. It should be reserved for emergencies, not routine practices. The indifferent style should not be applied in any (educational) institution that aims at effectiveness. With its characteristic lack of direction, indifference kills staff morale and, consequently, institutions as well.

\section{Limitations and Further Research}

The current study is limited by both its examination of only three of the five leadership styles of the managerial grid, and by its cross-sectional nature. A longitudinal study using an experimental design (with schools in both research and control groups) could, for example, perhaps have unveiled more layers of knowledge. Even then, the current study remains significant for its extension of leadership style narratives to a private secondary school setting in a developing country context of Buikwe District (Uganda), and for its underlining of the limitations of the teamwork style, its clear prevalence and immense value in educational administration and management notwithstanding.

Further research should therefore interest itself with a longitudinal study of the impact of different leadership styles on teacher performance; and it should preferably use an experimental design. For example, when a predominantly dictatorial style head teacher with time changes to use of the teamwork style, how much difference does the change make in teacher performance?

There is also need for further research on the relationship between the dictatorial and laissez-faire leadership styles on teacher performance, but only in those organisations where these styles are also found to be prevalently used. The current study correlated only one leadership style (teamwork) with teacher performance, since other styles were found to be rarely used in the study area.

\section{REFERENCES}

Aboshaiqah, A. E., Mansour, A. M. H., Sherrod, D. R., Alkhaibary, A., \& Alkhaibary, S. (2014). Nurses' perception of managers' leadership styles and its associated outcomes. American Journal of Nursing Research, 2 (4), pp. 57-62.

Adepoju, O. (2018). Introduction to educational administration and planning. Ikare Printing Press, 1(10-1-89-6009), 96-109.

Agwu, M. O. (2015). Teamwork and employee performance in the bonny Nigeria Liquefied Natural Gas Plant. Strategic Management Quarterly, 3(4), 39-60.

Ahmed, S. A. (2015). Managerial grid a magic wand for today's leadership. International Journal of business and administration research review, 1(12).

Akparep, J. Y., Jengre, E., \& Mogre, A. A. (2019). The influence of leadership style on organizational performance at Tumakavi Development Association, Tamale, Northern Region of Ghana. Openn Journal of Leadership Vol. 8, pp. 1-22.

Akram, M., Alam, H. M., Ali, L., \& Mughal, M. M. (2012). How leadership behaviors affect employee performance in Pakistan. Journal of Economics and Behavioral Studies, 4(6),

Al-Malki, M. \& Juan, W. (2018). Leadership styles and job performance: A literature review. Journal of International Business Research and Marketing, Vol. 3 (3); pp. 40-59.

Alonzo. M.L.M. (2018). The relationship between managerial grid model position and job satisfaction of regular employees of Bank X.

Amin, M.E. (2005). Social science research: Conception, methodology and analysis. Kampala: Makerere Printery.

Aquinas, P. G. (2008). Organizational behaviour: Concepts, realities, applications and challenges. New Delhi, India, Excel Books.

Aunga, D. A. O., \& Masare, O. (2017). Effects of leadership styles on teachers' performance in primary schools of Arusha District Tanzania. International Journal of Educational Policy Research and Review, 4(4), pp. 4252.

Ayene, T. A. (2016). Principals' leadership styles and their effects on teachers' performance in the Tigray Region of Ethiopia. Pretoria: University of South Africa.

Bakwai, B. S. (2015). Head teachers' leadership styles and staff performance in secondary schools in Nakaloke town council, Mbale district, Uganda.

Basit, A., Sebastian, V., \& Hassan, Z. (2017). Impact of leadership style on employee performance (A case study on a private organization in Malaysia). International. Journal of Accounting $\mathcal{E}$ Business Management, 5 (2), pp. 45-60. 
Bencherab,A. \& Maskari,A.A. (2021). Clinical supervision: A genius tool for teachers' professional growth. The Universal Academic Research Journal,3(2),51-57.

Bhargavi, S. \& Yaseen, A. (2016). Leadership styles and organizational performance. Strategic Management Quarterly, 4(1); pp. 87-117.

Biradar, B. B., \& Chatpalli, V. S. (2017). Assessing leadership style in multicultural team. AGU International Journal of Management Studies \& research (5), 264-269.

Blake, R. R., \& Mouton, J. S. (1985). The managerial grid: key orientations for achieving production through people. Houston, Tex: Gulf Pub. Co.

Blasé, J., Dedrick, C., \& Strathe, M. (2018). Leadership behavior of school principals in relation to teacher stress, satisfaction, and job performance. The Journal of humanistic education and development 24(4):159-171. DOI: $10.1002 / j .2164-4683.2018 . t b 00290 . x$

Buikwe District (2018). District Inspection Report 2018. The Ministry of Education and Sports (MoES).

Bush, T., \& Middlewood, D. (2005). Leading and managing people in education. London: SAGE publication limited.

Cho, K. W., Yi, S. H., \& Choi, S. O. (2018). Does Blake and Mouton's managerial grid work? The relationship between leadership type and organization performance in

South Korea. International Review of Public Administration, 23(2), 103-118.

Chua, J., Basit, A. and Hassan, Z (2018) Leadership style and its impact on employee performance International Journal of Accounting \& Business Management 6 (1).

Crawfurd, L. (2017). School Management and Public-Private Partnerships in Uganda. Munich Personal RePEc Archive. MPRA Paper No. 79923.

Dalluay, D. V. S. \& Jalagat, D. R. C., (2016). Impacts of leadership style effectiveness of managers and department heads to employees' job satisfaction and performance on selected small scale businesses in Cavite, Philippines. International Journal of Recent Advances in Organizational Behaviour and Decision Sciences (IJRAOB), 2(2), pp. 734-751.

Dastane, O. (2020). Impact of leadership styles on employee performance: A moderating role of gender. Australian Journal of Business and Management Research, Vol.05 No.12; pp. 27-52.

Davidescu, A. A., Apostu, S., Paul, A. and Casuneanu, I. (2020). Work Flexibility, job satisfaction, and job performance among Romanian employees - Implications for sustainable human resource management. Sustainability, 12 (6086); pp. 1-53.

Ejimabo, N. O. (2015). An approach to understanding leadership decision making in organization. European Scientific Journal, 11(11); pp. 1-24.

Esia-Donkoh, K. and Quansah, D. K. (2021). Leadership styles of principals based on setting, zone, and location of public colleges of education in Ghana. Education Quarterly Reviews, Vol. 4(2); pp. 443-454.

Genza, G. M. (2021). But what is leadership? A systematic review of the leadership concept in view of heightened educational leadership in Africa. Journal of Education and Practice. Vol. 12, No. 9; pp. 127137.

Genza. M. G., Muwagga, M. A., \& Ssempala, C. (2016). Secondary School Teachers' Professional Role Identity and Personal Role Espousal in Central Uganda: Lessons for Teacher Professionalism in Africa. International Journal of Social Science and Humanities Research 4(1), 192-203.

Ghodang, H. (2021). The effect of innovative leadership and job satisfaction on teacher's performance. International Journal of Education and Research, Vol. 9 (1); pp. 39-54.

Goddey, W. (2017). Principals' Leadership Style and Staff Job Performance in Selected Secondary Schools, Nigeria. International Multi-Disciplinary Journal, Ethiopia 11 (3); pp. 115-131.

GoU [Government of Uganda] (2013). Uganda Vision 2040. Kampala: Government of Uganda.

Hakan, K. Kiliclar, A. and Yazicioglu, I. (2013). Analyzing leadership styles of Turkish managers in the scope of the Blake and Mouton's managerial grid. International Journal of Business and Social Science, Vol. 4 (11); pp. 96-107.

Holberta, J., Madhakomala, R., Saparuddin and Timotius, E. (2021). The influence of leadership styles on employees' job satisfaction in public sector organizations in Indonesia. Management Science Letters, 11 (2021); pp. 1393-1398.

Igunnu,A.A. (2020). Leadership styles and job performance among administrative heads of secondary schools. The Universal Academic Research Journal,2(1),38-45 
Imhangbe, OS. Okecha, RE., and Obozuwa, J. (2018). Principals' leadership styles and teachers' job performance: Evidence from Edo State, Nigeria. SAGE Journals.

Iqbal, N., Anwar, S., \& Haider, N. (2015). Effect of leadership style on employee performance. Arabian Journal of Business Management Review, 5: 146. doi:10.4172/2223-5833.1000146.

Janelle, C. (December, 2018). "What is the Role of a Teacher?" Thoughtco.com/ what-is-the-role-of a- teacher2081511.

Joshi, B.S. (2015). Exploring leadership styles adopted by the top and middle level leaders from hospital industry in Pun city. Bharuch Research Centre for Health Management Studies.

Kakonge, L. M. (2018). Inspection and Education progress Report. Buikwe District, Uganda. The Ministry of Education and Sports (MoES).

Khajeh, E. H. A. (2018). Impact of leadership styles on organizational performance. Journal of Human Resources Management Research, DOI: 10.5171/2018.687849

Khan, M. A., Ismail, F. B., Hussain, A. and Alghazali, B. (2020). The interplay of leadership styles, innovative work behavior, organizational culture, and organizational citizenship behavior. SAGE Open, JanuaryMarch (2020); pp. 1-16.

Khorsan \& Crawford (2014). External validity: A conceptual approach for systematic review methodology.

Kiwanuka, M. C. (2017 March 18). Buikwe teachers arrive late for work and leave. The Ministry of Education and Sports (MoES).

Krejcie, R. V., \& Morgan, D. V. (1970). Determining sample size for research activities. Educational and psychological measurement, 30 (608).

Küçüker, M. S . (2019). The views of the teachers working in vocational high schools about lifelong learning. The Universal Academic Research Journal,1(1),11-26

Mawoli, M. A., \& Haruna, M. (2013). Effect of leadership styles on employees' job performance: Evidence from Federal Medical Centre in Niger State.

MoES (2017). Education \& sports sector annual performance (FY 2016/2017) [ESSAPR 2016/2017]. Kampala: Government of Uganda.

MoES (2019). Education E sports sector annual performance (FY 2018/2019) [ESSAPR 2018/2019]. Kampala: Government of Uganda.

MoES [Ministry of Education and Sports] (2008). Education Act 2008. Kampala: Government of Uganda.

Munir, H. and Iqbal, M. Z. (2018). A study of relationship between leadership styles of principals and job satisfaction of teachers in colleges for women. Bulletin of Education and Research, 40(2),65-78.

Muza,S.H.(2021). Team teaching approach on academic performance of students in faculty of education. The Universal Academic Research Journal,2(2),58-6

Nakidien, T., Singh, M. and Sayed, Y. (2021). Teachers and teacher education: Limitations and possibilities of attaining SDG 4 in South Africa. Education Sciences, Vol. 11(66); pp. 1-13.

Nasir, H. M., Nordin, R., Seman, S. A. A., \& Rahmat, A., (2014). The relationship of leadership styles and organizational performance among IPTA Academic Leaders in Klang Valley Area, Malaysia. Business \& Entrepreneurship Journal, 3(2); pp. 45-65.

Okeniyi, C. M. (1995). Relationship between leadership problems and school performance in Oyo State secondary schools. Unpublished Masters of Education dissertation; University of Ibadan.

Olaniyan, A. O. (1999). Principal preparation, selection and leadership roles: Teachers and teaching in Nigeria. Benin: Festa Press Ltd.

Sanyal, S., \& Hisam, M. W. (2018). The impact of teamwork on work performance of employees: A study of faculty members in Dhofar University. IOSR Journal of Business and Management (IOSR-JBM). 20 (3), $15-22$.

Sarışık, S. (2020). Investigation of the leadership qualifications of school managers in educational administration: The teachers' views . International Journal of Educational Research Review, 5 (4), 296-307. DOI: 10.24331 /ijere.748935

Specchia, M. L. et al. (2021). Leadership styles and nurses' job satisfaction: Results of a systematic review. International Journal of Environmental Research and Public Health, 18 (1552); pp. 1-15.

Ssekamwa, C.J. (2000). History and development of education in Uganda. Kampala: Fountain Publishers.

Ssekamwa, J. C. (1997). History and Development of Education in Uganda. Kampala: Fountain Publishers. 
Wachira, F. M., Gitumu, M., \& Mbugua, Z. (2017). Effect of principals' leadership styles on teachers' job performance in public secondary schools in Kieni West Sub County.

Wang, H., \& Guan, B. (2018). The Positive Effect of Authoritarian Leadership on Employee Performance: The Moderating Role of Power Distance. Frontiers in psychology, 9(357).

Yalçınkaya, S., Dagli, G., Altınay, F., Altınay, Z. and Kalkan, Ü. (2021). The effect of leadership styles and initiative behaviors of school principals on teacher motivation. Sustainability; 13 (2711); pp. 1-18.

Yao, L., Woan, K. S., Li, F. \& Ahmad, M. H. B. (2017). The relationship between leadership styles and employee engagement: Evidence from construction companies in Malaysia. The Social Sciences, 12, pp. 984-988.

Zikanga, D. K., Anumaka, B. I., Tamale, M. B. and Mugizi, W. (2021). Remuneration and job performance of teachers in government aided secondary schools in Western Uganda. Interdisciplinary Journal of Education Research, Vol 3 (2); pp 10-22. 